\title{
Penggunaan Software Sebagai Sumber Dan Media Pembelajaran Sekolah Di Masa Pandemi Covid-19: Studi Literatur
}

\author{
Jaja Jamaludin', Gingin Ginanjar², Euis Teti Halimah, Deden Sudrajat \\ Institut Pendidikan Indonesia-Garut \\ Program Studi Teknologi Pendidikan, Sekolah Pascasarjana \\ Institut Pendidikan Indonesiagarut \\ Email :jamaludinjaja206@gmail.com, 14gingin@ gmail.com, euistetihalimah16@ gmail.com, \\ sudrajatd712@gmail.com
}

\begin{abstract}
Abstrak. Analisis tinjauan pada studi literature terhadap artikel atau tulisan yang membahas tentang penggunaan software sebagai sumber dan media pembelajaran sekolah di masa pandemi covid-19. Metode yang digunakan pada jurnal ini adalah studi literature dengan mengunjungi beberapa halaman atau artikel dari world wide web, yang dilakukan dengan jenis naratif (pemaparan) terkait dengan topik penggunaan software sebagai sumber dan media pembelajaran sekolah di masa pandemi covid-19. Teknik analisis data yang dilakukan penulis adalah dengan melakukan penyaringan (apply filter), berdasarkan tahun yakni 2019-2020, judulnya yakni yang relevan dengan perangkat lunak komputer pembelajaran, dan topiknya. Secara keseluruhan, inti yang dibahas adalah perangkat lunak komputer yang populer ditengah pandemi, khususnya yang digunakan dalam pembelajaran di sekolah.
\end{abstract}

\section{Kata Kunci: Perangkat Lunak Komputer, Pembelajaran, Sekolah, Covid-19}

Abstract. Analysis of the review of the literature study of articles or writings that discuss the use of software as a source and medium of school learning in the co-19 pandemic. The method used in this journal is the study of literature by visiting several pages or articles from the world wide web, which is carried out with a narrative type (exposure) related to the topic of using software as a source and medium of school learning in the co-19 pandemic. The data analysis technique used by the writer is by applying filter, based on the year 2019-2020, the title of which is relevant to computer learning software, and the topic. Overall, the core discussed is computer software that is popular in the middle of a pandemic, especially those used in learning in schools.

Keyword: Sofware, Lerning-activities, School, Covid-19

\section{PENDAHULUAN}

Di masa pandemi Covid 19 ini, banyak orang yang semakin sadar akan pentingnya penggunaan software (perangkat lunak komputer) dalam rangka membantu kelangsungan proses pembelajaran daring. Pemerintah melalui Kementerian Pendidikan dan Kebudayaan juga telah menerbitkan Surat Edaran Nomor 3 Tahun 2020 tentang Pencegahan Covid-19 pada Satuan Pendidikan sebagai antisipasi terhadap penyebaran virus Corona Virus Disease 2019 (Covid-19) di berbagai sekolah maupun perguruan tinggi, menindaklanjuti anjuran Pemerintah tersebut serta merujuk pada Surat Edaran Direktur Nomor 229/PL21/KP/2020 tentang Lockdown untuk Pencegahan Penyebaran Infeksi Virus Corona (Covid-19) di SMAN 10 Garut, maka pelaksanaan kegiatan akademik dalam masa darurat penyebaran Covid 19 ditiadakan. Kegiatan pembelajaran tatap muka dan menggantinya dengan bekerja dari rumah (WFH) oleh guru dan belajar dari rumah (LFH) oleh siswa melalui pembelajaran daring dengan berbagai macam media (Zahrotunnimah, 2020)

Sekolah daring sebagai salah satu solusi pembelajaran dimasa covid ini merebak, dianggap cara yang terbaik untuk memutus mata rantai penyebaran virus ini (Dewi, 2020). Sekolah daring memberikan pembelajaran jarak jauh dimana bahan 
sekolah yang diberikan melalui software (perangkat lunak komputer) tentu akan memudahkan bagi siswa untuk tetap mendapatkan pembelajaran tanpa tatap muka. Pilihan ini harus diambil untuk melakukan tindakan pencegahan dan imitigasi yang efektif atas wabah yang kini telah menjadi pandemi global, di antara kebijakan yang diambil ialah menonaktifkan kegiatan persekolahan di lingkungan sekolah serta melakukan karantina mandiri siswa, guru dan tenaga kependidikan, karyawan lainnya dan termasuk tidak melakukan pertemuan tetapi melakukan pembelajaran dan bimbingan secara daring.

Karena pada hakikatnya proses belajar adalah proses komunikasi (proses penyampaian pesan) yang harus diwujudkan melaui kegiatan penyampaian dan tukar menukar pesan atau informasi oleh setiap guru dan siswa. Pesan atau informasi dapat berupa pengetahuan, keahlian, skill, ide, pengalaman dan sebagainya. Melalui proses komunikasi, pesan atau informasi dapat diserap dan dihayati oleh orang lain. Di masa pandemi ini jelas muncul kecenderungan pemanfaatan/pendayagunaan software. Software adalah kumpulan dari program yang digunakan untuk menjalankan aplikasi tertentu pada komputer, sedangkan program merupakan kumpulan perintah komputer yang tersususn secara sistematis(Darmawan, Deni, Nur Fauzi 2016:73) . Kemampuan untuk menggunakan beragam perangkat lunak mutlak dimiliki oleh siswa masa kini agar dapat melakukan pembelajaran daring serta lebih mudah menyesuaikan diri dengan kemajuan teknologi.

\section{TINJAUAN PUSTAKA}

Strategi kognitif merupakan kemampuan internal yang terorganisir yang dapat membantu peserta didik dalam proses belajar, proses berpikir memecahkan masalah, dan mengambil keputusan.(Surya, 2015)

Dalam pendapat yang lain Dikatakan bahwa: "Cognitive Strategy Instruction (CSI) is a very broad subject but here you will find anoverview of the process and practical tips. For more in depth study references are
provided.CSI is a tool intended to help students develop the necessary skills to be self-regulated learners."(Reid, 2005).

Berdasarkan pada pandangan ini, pembelajaran yang menerapkan strategi kogntif memberikan alat kepada peserta didik yang memungkinkan, dengan alat itu, peserta didik mengembangkan keterampilannya dan melakukan sendiri. Pembelajaran dengan strategi kognitif bukanlah serangkaian langkah khusus. Dicontohkan pada saat pembelajaran membaca, agar peserta didik dapat membaca dengan baik maka yang harus dilakukan guru ialah membekali peserta didik dengan strategi. Strategi dimaksud, yaitu menggunakan who, what and wheree . dalam proses membaca agar para peserta didik dapat menghasilkan atau membuat pertanyaan yang mengantarkan mereka mengerti apa yang mereka baca.

Fungsi Software - Dalam peran yang penting dalam berjalannya sistem komputer, tentu memiliki fungsi-fungsi khusus yang dimiliki software. Fungsi-fungsi software tersebut antara lain sebagai berikut.

- Software menyediakan fungsi dasar untuk kebutuhan komputer yang dapat dibagi menjadi sistem operasi atau sistem pendukung

- Software berfungsi dalam mengatur berbagai hardware untuk bekerja secara bersama-sama.

- Sebagai penghubung antara softwaresoftware yang lain dengan hardware

- Sebagai penerjemah terhadap softwaresoftware lain dalam setiap instruksiinstruksi ke dalam bahasa mesin sehingga dapat di terima oleh hardware(Zaenuddin, 2015).

Mengidentifikasi programBerdasarkan fungsinya, Software komputer terbagi dalam tiga jenis, yaitu: (1) Operating System (Sistem Operasi), (2) Application Software (Program Aplikasi), (3) Programming Languange (Bahasa Pemrograman).

Sistem operasi adalah pearangkat lunak (software) pada komputer yang bertugas untuk mengontrol dan memanajemen perangkat keras dan sebagai oprasi-oprasi dasar sistem termasuk dalam menjalankan 
software aplikasi misalnya program-program pengolah data untuk mempermudah kegiatan manusia(Setiawan 2017:57).

Sistem oprasi berfungsi untuk mengatur dan mengawasi penggunaaan perangkat keras oleh berbagai progran aplikasi serta para pengguna. Berikut adalah beberapa fungsi dari sistem oprasi diantaranya (Darmawan, Deni, Nur Fauzi 2016:77):

- Menjalankan komputer saat komputer pertamakali dijalankan.

- Menjalankan program aplikasi.

- Menjalankan program untility.

- Mengelola File.

- Menjalankan mode batch (Menumpuk data sebelum diolah)

- Memberi layanan pencetakan data di layar dan printer serta menyimpan data di file.

Tabel 1. Macam Sistem Operasi menurut (Yunaeti, Anggraeni, Elisabet, 2017)

\begin{tabular}{|c|c|}
\hline $\begin{array}{l}\text { Sistem } \\
\text { Operasi }\end{array}$ & Keterangan \\
\hline DOS & $\begin{array}{l}\text { Sistem operasi yang awalnya } \\
\text { dipakai pada IBM PC (disebut } \\
\text { (PC-DOS) dan PC yang } \\
\text { kompatibel dengan IBMPS } \\
\text { (disebut MS-DOS). Saat ini } \\
\text { sistem ini hamper tidak } \\
\text { digunakan lagi. }\end{array}$ \\
\hline $\begin{array}{l}\text { Windows 95/ } \\
\text { Windows 98/ } \\
\text { Windows } \\
\text { Me/ } \\
\text { Windows XP } \\
\text { Windows } 7 \\
\text { Windows } 8 \\
\text { Windows } 10\end{array}$ & $\begin{array}{l}\text { Sistem informasi dengan } \\
\text { antarmuka grafis yang dibuat } \\
\text { oleh Microsoft. Memiliki } \\
\text { kemampuan multitasking dan } \\
\text { dapat digunakan untuk } \\
\text { membentuk kerja tim dengan } \\
\text { membuat jaringan sederhana. } \\
\text { Dapat digunakan sebagai } \\
\text { klien dalam client/server. }\end{array}$ \\
\hline $\begin{array}{l}\text { Windows } \\
\text { NT/ } \\
\text { Windows } \\
2000\end{array}$ & $\begin{array}{l}\text { Sistem informasi dengan } \\
\text { antarmuka grafis ini biasa } \\
\text { digunakan sebagai server. } \\
\text { Mendukung multitasking dan } \\
\text { multiprocessing. }\end{array}$ \\
\hline $\mathrm{OS} / 2$ & $\begin{array}{l}\text { Sistem operasi untuk IBM PC } \\
\text { dengan antarmuka grafis. } \\
\text { Mendukung multitasking dan } \\
\text { networking. Namun kurang } \\
\text { popular di Indonesia. }\end{array}$ \\
\hline
\end{tabular}

\begin{tabular}{|l|l|}
\hline \multirow{3}{*}{ UNIX } & $\begin{array}{l}\text { UNIX adalah keluarga sistem } \\
\text { operasi yang dapat digunakan } \\
\text { di berbagai platform } \\
\text { computer, dari PC hingga } \\
\text { mainframe. }\end{array}$ \\
\hline \multirow{5}{*}{ LINUX } & $\begin{array}{l}\text { Sistem operasi semacam } \\
\text { UNIX ini sangat popular } \\
\text { dilingkungan perguruan } \\
\text { tinggi, terutama yang } \\
\text { mempunyai jurusan computer } \\
\text { atau informatika, dan telah } \\
\text { menjadi pesaing sistem } \\
\text { Windows sejak akhir tahun } \\
\text { 90-an. Sistem operasi ini } \\
\text { dapat menjadi pilihan bagi } \\
\text { orang-orang yang tak mau } \\
\text { membeli sistem operasi } \\
\text { komersial, karena bersifat } \\
\text { gratis. }\end{array}$ \\
\hline
\end{tabular}

Pernahkah Anda menggunakan suatu program untuk mengolah kata (word) atau bekerja dengan menggunakan programprogram seperti Microsoft Office Word, Excel, Powerpoint dan Access ?. Kalau jawaban Anda pernah, maka sebenarnya Anda telah menggunakan suatu program aplikasi (application program). Perlu dicatat bahwa Microsoft Office bukanlah sistem operasi, melainkan hanya suatu kelompok program aplikasi (perangkat/ piranti lunak).

Perangkat lunak sistem aplikasi (aplikasi software) merupakan perangkat lunak yang biasa digunakan oleh siapa saja untuk membanyu pekerjaannya. Perangkat lunak aplikasi dapat digolongkan menjadi dua macam yaitu (Setiawan 2017:75)

\section{a. Program Aplikasi}

Program aplikasi merupakan program yang langsung dibuat oleh seorang programer yang disesuaikan dengan kebutuhan seseorang ataupun untuk kebutuhan suatu perusahaanbiasanya menggunakan suatu bahasa pemograman.Contoh dari program aplikasi adalah
1) Program penggajian karyawan
2) Program penjualan tiket pesawat / kapal
3) Program kasir 
4) Program billing warnet dan lain sebagainya

b. Program Paket

Program peket merupakan program khusus dalam paket - paket tertentu yang dibuat oleh software house atau langsung bawaan dari sistem oprasi, ada beberapa contoh program aplikasi paket diantaranya :

1) Program pengolak kata contohnya adalah : Microsoft Word, Open Office. Org Writter, Chi Writter, Amipro dll.

2) Program pengolah angka contohnya : Microsoft Excel, Open Office .org Calc, Quattro Pro, Lotus 123, dll.

3) Program Presentasi contohnya adalah : Microsoft Power Point, Open Office.org Impres, Magic Point, Corel Presentation, Apple Work, dll.

4) Program Desain grafist contohnya adalah : Adobe Photoshop, Corel Draw, Free Hand, Auto Cad, dll.

5) Program browser contohnya adalah : Internet Explorer, Mozilla Firefox, Opera, Netscape Communicator.

6) Program database contohnya adalah : Microsoft Acces, Open Office.org Base, Virtual Foxpro, Fox Base, dll

7) Program animasi contohnya adalah : Macromedia Flash, Swish dll

8) Program Multimedia contohnya adalah : Windows Media Player, Winamps, Ciberlink, Rear Player, dll

9) Antivirus contohnya adalah : Avira, AVG, Smadaf DLL

Sistem aplikasi akan dapat berguna jika dan hanya jika sistem operasi telah terinstal sebelum terinstalnya sistem aplikasi. Program Aplikasi adalah program (kumpulan instruksi) yang dibuat atau dirancang untuk tujuan tertentu atau khusus, artinya bahwa sistem aplikasi dibuat sesuai dengan domain permasalahan.(Yahfizham, 2019)
Bahasa Pemrograman adalah bahasa yang digunakan untuk membuat program itu sendiri. Ada banyak bahasa pemrograman, contohnya: Bahasa $\mathrm{C}, \mathrm{C}++$, Visual Basic, Pascal, Borland, HTML, dan masih banyak lagi yang lainnya(Yunaeti, Anggraeni, Elisabet, 2017). Bahasa pemograman juga akan menentukan bagaimana data akan disimpan, dikirim dan mendapatkan kembali data tersebut serta apa yang akan dilakukan selanjutnya jika terdapat kondisi yang beragam seperti misalnya dalam memberikan instruksi prioritas terhadap peralatan I/O (input/output), multimedia dan lain-lain (Yahfizham, 2019).

besar $\begin{gathered}\text { Software dibagi menjadi tiga bagian } \\ \text { berdasarkan }\end{gathered}$
(Muyono,Sugi,Agus, 2008), yaitu software berbayar, anda harus membelinya terlebih dahulu sebelum dapat menggunakannya, software gratis (freeware), anda bisa menggunakannya tanpa memerlukan uang, dan terakhir, software gratis dengan ketentuan (shareware), anda bisa menggunakannya gratis dalam jangka waktu tertentu dalam versi trial/ uji coba misal 30 hari. Setelah itu anda perlu membelinya dalam versi utuh.

Etika penggunaan software (perangkat lunak komputer) adalah perlu adanya undangundang hak cipta atas perangkat lunak. Setiap komputer harus mendapatkan izin pemakaian atau lisensi dari perusahaan yang mengeluarkan software (perangkat lunak) tersebut. Contohnya jika perusahaan komputer ingin menjual komputernya, maka perusahaan harus menyertakan dengan software asli yang telah ter-install di PC yang dijualnya.

\section{METODOLOGI}

Metode yang digunakan pada jurnal ini adalah studi literature dengan mengunjungi beberapa halaman atau artikel dari world wide web, yang dilakukan dengan jenis naratif (pemaparan) terkait dengan topik penggunaan software dalam pembelajaran perkuliahan di masa pandemi covid-19. Teknik analisis data yang dilakukan penulis adalah dengan melakukan penyaringan (apply filter), berdasarkan tahun yakni 2019-2020, 
judulnya yakni yang relevan dengan software pembelajaran, dan topiknya. Kriteria pada judulnya, setidaknya terdapat kata software, aplikasi, Pembelajaran, sekolah, dan pandemi. Dengan demikian penulis

dapat lebih menyaring artikel dan mencocokkan pokok bahasan yang menjadi inti permasalahannya untuk dijadikan bahan bacaan dan rujukan pada ulasan jurnal ini.

\section{HASIL DAN PEMBAHASAN}

Penulis memperoleh beberapa temuan dari beberapa artikel yang menjadi bahan bacaan pada ulasan jurnal ini, menunjukkan begitu banyaknya penggunaan software (perangkat lunak) dalam proses pembelajaran sekolah di masa pandemi covid-19. Terkadang kita menyebut software dengan sebutan 'aplikasi' atau 'program'. Dengan adanya software, membuat komputer dapat difungsikan dengan baik untuk menunjang aktifitas kita, terlebih di masa pandemi. Contohnya, ketika kita ingin menulis laporan, membuat desain gambar, atau sekedar mendengarkan musik ketika rebahan \#dirumahaja. Apalagi mahasiswa, yang notabene-nya harus tetap melakukan proses pembelajaran daring, dengan banyak membutuhkan berbagai software pendukung.

Tabel 2. Software pembelajaran daring beberapa Sekolah di Indonesia

\begin{tabular}{|c|c|c|}
\hline No. & Software & Keterangan \\
\hline 1. & $\begin{array}{l}\text { Zoom cloud } \\
\text { meeting }\end{array}$ & $\begin{array}{l}\text { Zoom adalah layanan } \\
\text { konferensi } \\
\text { berbasis } \\
\text { computing. Aplikasi ini } \\
\text { mengizinkan pengguna } \\
\text { untuk bertemu dengan } \\
\text { orang lain secara } \\
\text { virtual, didirikan pada } \\
\text { tahun 2011 oleh Eric } \\
\text { Yuan. Zoom menjadi } \\
\text { naik daun akibat wabah } \\
\text { virus covid-19. Laporan } \\
\text { terbaru menunjukkan } \\
\text { pengguna harian zoom } \\
\text { mencapai } 300 \text { juta } \\
\text { beberapa }\end{array}$ \\
\hline
\end{tabular}

\begin{tabular}{|c|c|c|}
\hline & & $\begin{array}{l}\text { terakhir.Junlah tersebut } \\
\text { meningkat lebih dari } 50 \\
\text { persen. Kini zoom } \\
\text { menjadi nomor satu. Di } \\
\text { tengah pandemi virus } \\
\text { yang melemahkan } \\
\text { perekonomian dunia, } \\
\text { Eric Yuan menjadi } \\
\text { miliarder yang } \\
\text { menguasai pasar saham. } \\
\text { Kekayannya mencapai } \\
\text { USD 20 juta atau } \\
\text { sekitar Rp300 miliar. }\end{array}$ \\
\hline 2. & $\begin{array}{l}\text { Google } \\
\text { Classrom }\end{array}$ & 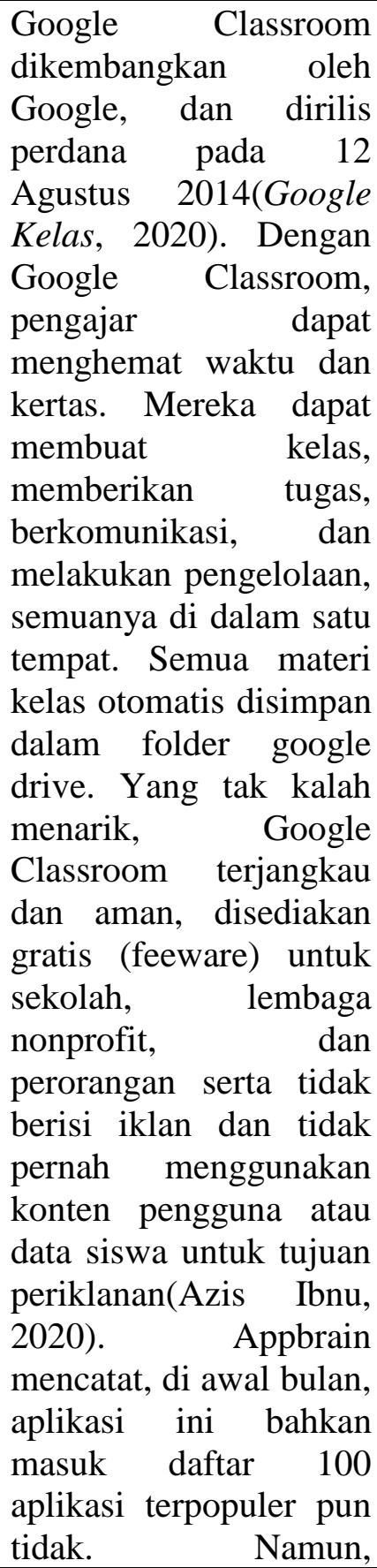 \\
\hline
\end{tabular}




\begin{tabular}{|c|c|c|}
\hline & & $\begin{array}{l}\text { peringkatnya meluncur } \\
\text { mulai 10 Maret di daftar } \\
5 \text { aplikasi terpopuler. } \\
\text { Negara-negara dengan } \\
\text { angka download } \\
\text { tertinggi adalah } \\
\text { Indonesia Mexico, } \\
\text { Kanada, Finlandia, } \\
\text { Italia, dan Polandia. }\end{array}$ \\
\hline 3. & $\begin{array}{l}\text { Google } \\
\text { Meet }\end{array}$ & $\begin{array}{l}\text { Google Meet } r \text { adalah } \\
\text { sebuah platform } \\
\text { komunikasi } \\
\text { dikembangkan } \\
\text { Google, termasuk pesan } \\
\text { instan, percakapan } \\
\text { video, SMS, dan fitur } \\
\text { VOI, dirilis perdana } \\
\text { pada tahun 2017(Satani, } \\
\text { 2020). Software ini } \\
\text { gratis, dan dapat } \\
\text { melakukan video } \\
\text { konferensi dengan } 100 \\
\text { Anggota serta tampilan } \\
\text { video berkualitas di atas } \\
\text { rata- rata. Google Meet } \\
\text { dahulunya terkenal } \\
\text { dengan Google Hangout } \\
\text { Meet mencatat telah } \\
\text { melewati 100 juta } \\
\text { pengguna aktif harian } \\
\text { dan menambah sekitar } \\
\text { tiga juta pengguna baru } \\
\text { setiap hari. }\end{array}$ \\
\hline 4. & $\begin{array}{l}\text { Google } \\
\text { Forms }\end{array}$ & $\begin{array}{l}\text { Google Form atau yang } \\
\text { disebut google formulir } \\
\text { adalah alat yang } \\
\text { berguna } \\
\text { membantu untuk } \\
\text { merencanakan acara, } \\
\text { mengirim survei, } \\
\text { memberikan siswa atau } \\
\text { orang lain kuis, atau } \\
\text { mengumpulkan } \\
\text { informasi yang mudah } \\
\text { dengan cara yang } \\
\text { efisin(Mengenal Google } \\
\text { Form untuk Kebutuhan } \\
\text { Survey Anda, tanpa } \\
\text { tanggal). Form juga } \\
\text { dapat dihubungkan ke }\end{array}$ \\
\hline
\end{tabular}

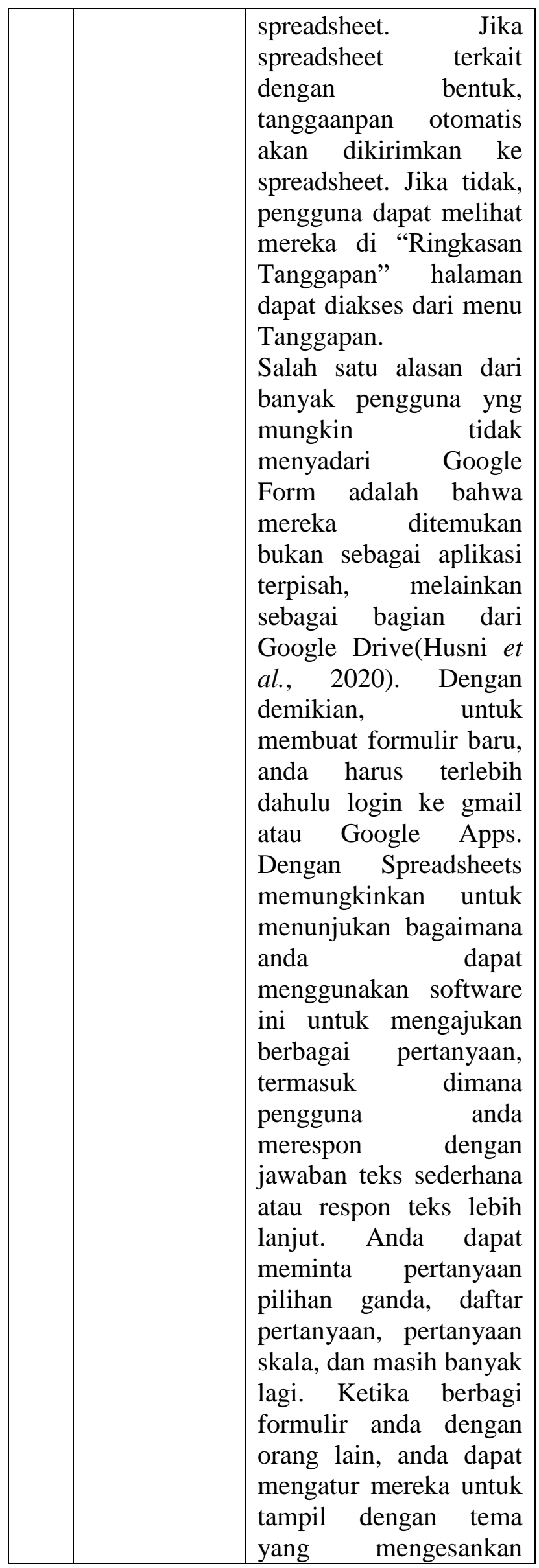




\begin{tabular}{|c|c|c|}
\hline & & $\begin{array}{lll}\text { dengan akses } & \text { yang } \\
\text { mudah. } & & \end{array}$ \\
\hline 5. & Webex & $\begin{array}{lr}\begin{array}{l}\text { Software ini } \\
\text { melakukan }\end{array} \\
\text { konferensi video } \\
\text { jumlah peserta } \\
\text { orang dengan } \\
\text { panggilan telefon dan } \\
\text { kualitas sangat baik. } \\
\text { Cisco Webex juga } \\
\text { dilengkapi beberapi } \\
\text { fitur seperti screen } \\
\text { sharing, } \\
\text { Assistant, Google Home } \\
\text { Hub, fitur pengunggah } \\
\text { dokumen, fitur perekam } \\
\text { percakapan video, } \\
\text { bahkan tersedia pula } \\
\text { papan virtual untuk } \\
\text { menggambar(Ventayen } \\
\text { et al., 2020)(Sharma, } \\
\text { 2012). }\end{array}$ \\
\hline 6. & Skype & 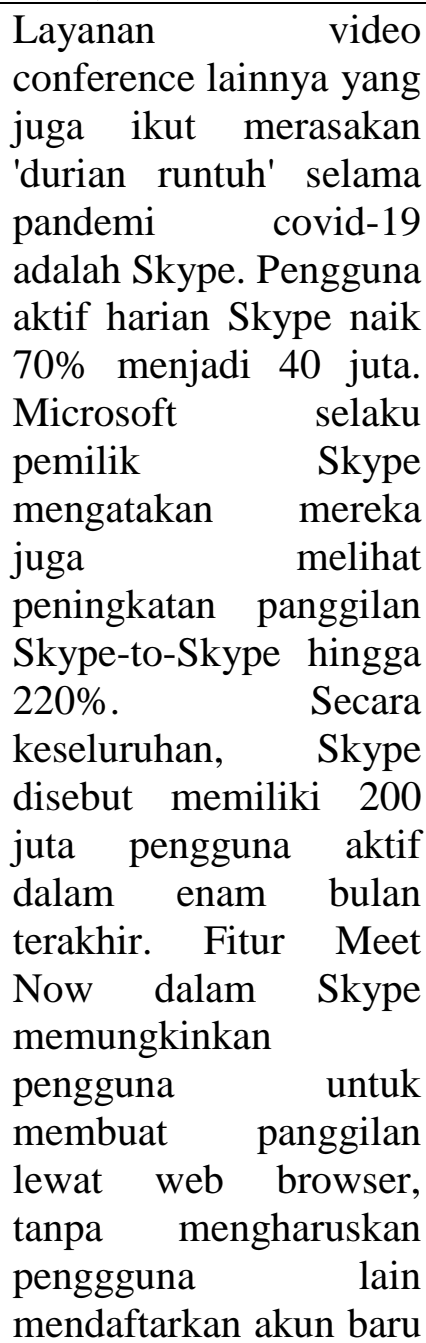 \\
\hline
\end{tabular}

\begin{tabular}{|c|c|c|}
\hline & & $\begin{array}{l}\text { atau mengunduh } \\
\text { software (Mugunthan, } \\
\text { Shanmugamurthy dan } \\
\text { Lakshmeekanth, } \\
\text { 2020)(Daffalla, } \\
\text { 2014)(Srimathi dan } \\
\text { Krishnamoorthy, 2019). }\end{array}$ \\
\hline 7. & Edmodo & 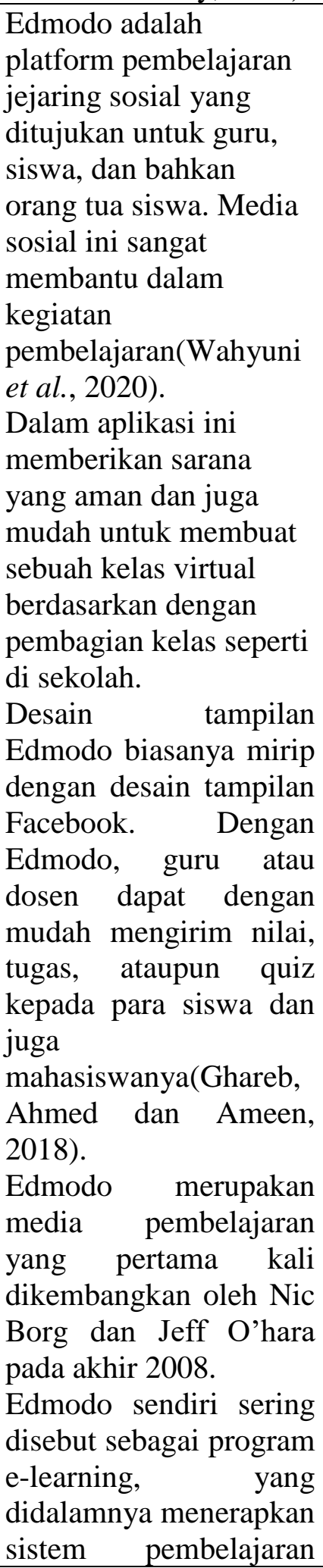 \\
\hline
\end{tabular}




\begin{tabular}{|c|c|c|}
\hline & & $\begin{array}{l}\text { yang sangat sederhana, } \\
\text { efektif, efisien dan juga } \\
\text { menyenangkan(Pinca, } \\
\text { 2015). } \\
\text { Media sosial ini telah } \\
\text { berkembang menjadi } \\
\text { salah satu jejaring sosial } \\
\text { yang tumbuh sangat } \\
\text { cepat di awal tahun } \\
\text { 2011. Hal ini bisa } \\
\text { dilihat dari jumlah } \\
\text { penggunanya yang } \\
\text { sudah mencapai } 1 \text { juta. } \\
\text { Hanya butuh beberapa } \\
\text { bulan saja, pengguna } \\
\text { dari media sosial ini } \\
\text { telah berkembang } \\
\text { menjadi } 7 \text { juta orang. } \\
\text { Pada akhir tahun } 2015 \\
\text { sudah ada sekitar } 50 \\
\text { juta pengguna Edmodo } \\
\text { dari berbagai belahan } \\
\text { dunia.(. dan Sumbawati, } \\
\text { 2014) }\end{array}$ \\
\hline 8. & $\begin{array}{c}\text { Whatsapp } \\
\text { Group }\end{array}$ & $\begin{array}{l}\text { Whatsapp saat ini } \\
\text { merupakan aplikasi } \\
\text { obrolan paling laris di } \\
\text { dunia. Aplikasi ini } \\
\text { memang } \\
\text { memiliki fitur audio call } \\
\text { dan video call, namun } \\
\text { tampaknya masih } \\
\text { kurang pas atas } \\
\text { performanya di tengah } \\
\text { pandemi ini, sehingga } \\
\text { berniat meningkatkan } \\
\text { kualitasnya } \\
\text { besaran, besar- } \\
\text { Whatsapp Saat ini } \\
\text { melakukan video call } \\
\text { dengan jumlah peserta } \\
\text { terbatas, namun ini akan } \\
\text { segera di perbaiki } \\
\text { (Suarniki et al., 2019) }\end{array}$ \\
\hline 9. & $\begin{array}{c}\text { Microsoft } \\
\text { Teams }\end{array}$ & $\begin{array}{l}\text { Microsoft Teams adalah } \\
\text { sebuah platform } \\
\text { komunikasi dan } \\
\text { kolaborasi terpadu yang } \\
\text { menggabungkan fitur } \\
\text { percakapan kerja, rapat }\end{array}$ \\
\hline
\end{tabular}

\begin{tabular}{|l|l|}
\hline video, penyimpanan \\
berkas $\quad$ termasuk \\
kolaborasi pada berkas), \\
dan integrasi aplikasi. \\
Aplikasi ini terintegrasi \\
dengan langganan \\
Office 365 dan juga \\
dapat diintegrasikan \\
dengan produk selain \\
buatan Microsoft. \\
Microsoft Teams adalah \\
kompetitor Slack, serta \\
merupakan hasil evolusi \\
dan peningkatan dari \\
Microsoft Skype for \\
Business. \\
Microsoft \\
mengumumkan Teams \\
pada sebuah acara di \\
New York, dan resmi \\
meluncurkannya pada \\
tanggal 14 Maret 2017. \\
Aplikasi ini dibuat pada \\
sebuah ajang hackathon \\
internal, dan kini \\
dipimpin oleh Brian \\
MacDonald, Wakil \\
Presiden Korporat \\
Microsoft.(Microsoft \\
Teams, tanpa tanggal) \\
(Noor et al., \\
2020)(Kreedy, \\
2014)(Ananthi Claral \\
Mary dan Arul Leena \\
Rose, 2019)
\end{tabular}

\section{KESIMPULAN}

Dampak covid-19 sangat terlihat jelas bagi proses pembelajaran sekolah. Kebijakan pembelajaran daring juga membuat sekolahsekolah melakukan sistem pembelajaran secara daring guna melakukan komunikasi untuk menunjang aktifitas pembelajaran dirumah. Tidak hanya siswa, para guru juga berusaha memberikan pembelajaran yang menarik dan efektif demi memenuhi kewajibannya secara maksimal. Banyak guru yang menggunakan software (perangkat lunak) yang menunjang proses pembelajaran 
daring, diantaranya google classroom, zoom, google meet, serta aplikasi lainnya.

\section{DAFTAR PUSTAKA}

S. dan Sumbawati, M. (2014) "Pengembangan Media Pembelajaran E-Learning Berbasis Edmodo Pada Kompetensi Dasar Menerapkan Konsep Dasar Sistem Komunikasi Data Sinyal Digital Melalui Media Kabel Fiber Dan Frekuensi Radio Di Smk Negeri 1 Jetis Mojokerto," Jurnal Pendidikan Teknik Elektro, 3(2).

Ananthi Claral Mary, T. dan Arul Leena Rose, P. J. (2019) "Implications, risks and challenges of cloud computing in academic field - a state-of-art," International Journal of Scientific and Technology Research, 8(12), hal. 3268-3278.

Azis Ibnu (2020) mengenal-googleclassroom- fungsi-dan- caramenggunakannya, www.tirto.id. Tersedia pada: www.tirto.id (Diakses: 10 Agustus 2020).

Daffalla, A. (2014) "The Impact of Facebook and Others Social Networks Usage on Academic Performance and Social Life among Medical Students at Khartoum University," International Journal of Scientific \& Technology Research, 3(5), hal. 4146.

Darmawan, Deni, Nur Fauzi, K. (2016) Sistem Informasi Manajemen. 4 ed. Diedit oleh A. Kamsyach. Bandung: PT Remaja Rosdakarya. Tersedia pada: www.rosda.com.

Dewi, W. A. F. (2020) "Dampak Covid-19 Terhadap Implementasi Pembelajaran Daring Di Sekolah Dasar.," Edukatif: Jurnal Ilmu Pendidikan, 2(1), hal. 55-61. doi: https://doi.org/10.31004/edukatif.v2i 1.89.

Ghareb, M. I., Ahmed, Z. A. dan Ameen, A. A. (2018) "The role of learning through social network in higher education in krg," International
Journal of Scientific and Technology Research, 7(5), hal. 20-27.

Google Kelas (2020) d.m.wikipedia.org. Tersedia pada: https://id.m.wikipedia.org/ (Diakses: 10 Agustus 2020).

Husni, H. et al. (2020) "Preferable Applications for Home-Based Learning during the Coronavirus ( COVID-19 ) Outbreak in Indonesia Islamic Higher Education," 9(06).

Kreedy, A. I. (2014) "Metrics Tools For Reengineering Software Projects," International Journal of Scientific \& Technology Research, 3(9), hal. 360365.

Mengenal Google Form untuk Kebutuhan Survey Anda (tanpa tanggal) www.dcloudhost.com/. Tersedia pada: https://idcloudhost.com/.

Microsoft Teams (tanpa tanggal) https://id.wikipedia.org. Tersedia pada: https://id.wikipedia.org (Diakses: 10 Agustus 2020).

Mugunthan, S. R., Shanmugamurthy, A. P. dan Lakshmeekanth, A. (2020) "A sensitive model for aggregation of significant whatsapp messages in social networking," International Journal of Scientific and Technology Research, 9(2), hal. 5225-5228.

Muyono,Sugi,Agus, S. (2008) Kumpulan Software Pilihan Yang Paling Dicari. Jakarta: Mediakita.

Noor, H. et al. (2020) "Brief Comparison Of Cloud' $s$ Emerging Services: A Literature Review," 9(06).

Pinca, E. C. (2015) "The Mobile Teachers Profile Competencies Performance And Problems In The Department Of Education Division Of Northern Samar Philippines," International Journal of Scientific \& Technology Research, 4(8), hal. 45-50.

Reid, G. (2005) Cognitive Strategy Instruction (CSI). 1 ed. Diedit oleh W. Cromwell Press, Trowbridge. Thousand Oaks, California 91320: Cromwell Press, Trowbridge, Wiltshire. 
Satani (2020) Google Meet, https://en.m.wikipedia.org. Tersedia pada: https://en.m.wikipedia.org.

Setiawan, R. (2017) KOMPUTER DAN JARINGAN DASAR Bidang Keahlian Teknologi Informasi dan Komunikasi. Diedit oleh K. Pramono, Budi. Surakarta: CV. Mediatama.

Sharma, A. (2012) "Data Management and Deployment of Cloud Applications in Financial Institutions and its Adoption Challenges," International Journal of Scientific \& Technology Research, 1(1), hal. 25-31.

Srimathi, H. dan Krishnamoorthy, A. (2019) "The impact of social computing tools in multinational student project," International Journal of Scientific and Technology Research, 8(9), hal. 2224-2227.

Suarniki, N. N. et al. (2019) "Community as a driver of smes growth in indonesia," International Journal of Scientific and Technology Research, 8(10), hal. 2740-2744.

Surya, M. (2015) STRATEGI KOGNITIF DALAM PROSES PEMBELAJARAN. 1 ed. Diedit oleh H. Abdul. Bandung: Alfabeta.

Ventayen, R. J. M. et al. (2020) "Senior high school teachers' practices and readiness in blended learning environment: Basis for a blended learning preparedness framework," International Journal of Scientific and Technology Research, 9(2), hal. 2163-2168.

doi: $10.2139 /$ ssrn.3504189.

Wahyuni, S. et al. (2020) "Integrating edmodo into english instruction: Students' perceptions and its contribution to autonomous learning," International Journal of Scientific and Technology Research, 9(2), hal. 1590-1595.

Yahfizham (2019) Dasar-dasar Komputer. Medan. Tersedia pada: Perdana.

Yunaeti, Anggraeni, Elisabet, I. (2017) Pengantar Sistem Informasi. Diedit oleh E. Risanto. Yogyakarta: ANDI. Zaenuddin (2015) Pengertian Software, Fungsi, Jenis-Jenis dan Contohnya, https://artikelsiana.com. Tersedia pada: https://artikelsiana.com (Diakses: 10 Agustus 2020).

Zahrotunnimah, Z. (2020) "Langkah Taktis Pemerintah Daerah Dalam Pencegahan Penyebaran Virus Corona Covid-19 di Indonesia," SALAM: Jurnal Sosial dan Budaya Syar-i, 7(3). doi: 10.15408/sjsbs.v7i3.15103. 